\title{
T5 Stage Finding
}

National Cancer Institute

\section{Source}

National Cancer Institute. T5 Stage Finding. NCI Thesaurus. Code C132010.

An antiquated primary tumor finding term that refers to colorectal cancer which has spread by direct extension beyond the immediately adjacent organs or tissues. (AJCC 1st Ed.) 